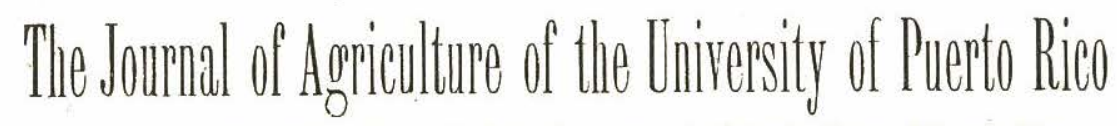

In continuation of The Journal of the Department of Agriculture of Puerto Rico

Published Quarterly: January, A pril, July and October of each year.

Merville T. Cook, editor

\begin{tabular}{lll}
\hline Vol. XX & A PRIL 1936 & No. 2 \\
\hline
\end{tabular}

\title{
BUTYRIC ACID BY FERIMENTATION
}

\begin{abstract}
By Rafael Arroyo,
Chief, Division of Chemistry, Agricultural Experiment Station of the College of Agriculture of the University of Puerto Rico, Río Peidras, P. R.
\end{abstract}

\section{INTRODUCTION}

The writer has been interested in industrial fermentation problems since 1929. On various occasions he has expressed his firm belief in the glorious future awaiting fermentation processes in the field of organic industrial chemistry. He has, moreover, expressed his belief that no other territory is better adapted to industrial fermentation work than the tropies; especially in its application to carbohydrate material. The products, by-products, and so-called waste products of the sugar-cane industry offer an abundant and cheap supply of raw material; while the microbiological flora offers in a generous measure the organisms through whose agency the transformation of carbohydrate raw material into useful .chemicals will take place.

In the summer of 1931 the writer started a research for the production of butyl alcohol and acetone by a special fermentation carried on blackstraps through the agency of an organism, (B. Tetryl), discovered and isolated by him.

In March, 1934, patent application was made before the U. S. Patent Office for this process, and patent rights were granted by the Examiner in April 1935. English patent application is now pending.

A detailed account of the laboratory work connected with this research was published in the October 1934 number of "The Journal of Agriculture of the University of Puerto Rico", which was issued on December of the same year.

In the second part of that publication, mention was made of another investigation started during 1933 along similar lines; this time the work aiming at the production of N. Butyric Acid from blackstrap molasses. The purpose of this paper is to give a full account of the results of this new investigation. 
The writer's intention being to apply for patent rights protection for this new process, and eventually enter into its commercial exploitation, he has already presented a petition to the "Board of Trustees of the University of Puerto Rico" to grant him their consent and approval of this action.

\section{Butyric Acid is a Valuable and Important Acid}

Butyric acid is one of the most valuable aliphatic acids used commercially; its main drawback to an extended use in the chemical industries being its unnecessary and inexplicable high price. In striking contrast with the declining values that were prevalent in the New York Chemical Market from the latter part of 1929 to the first half of 1934, the price of N. Butyric Acid remained practically constant at 80 cents per pound, based on hundred-percent acid. Recently the introduction of synthetic butyric acid by the Carbon and Carbide Corporation has had a detrimental effect on the price of this commodity; but even so, the price remains too high to encourage a carload use for this chemical. With a view to find a process that would make it possible to sell N. Butyric Acid, with a profit, at a price less than its present cost, this investigation was effected. The success encountered in our previous investigation on the production of butanol and acetone by fermentation, encouraged us to try similar methods in this new study.

\section{Difficulties Encountered by Previous Investigators}

Although processes leading to the production of organic acids by fermentation have been practiced from time inmemorial, the mechanism whereby these processes took place, or the agents responsible for them, were utterly ignored. The production of butyric acid remained in the situation common to all these processes until Pasteur recognized the butyric fermentation as a well defined microbiological phenomenon; describing this fermentation as an anaerobic process before the Academy of Science in Paris, 1861.

Since this date, many groups of these organisms have been found and their products of fermentation studied by several well-known investigators; among which we may mention Kirov; Baier; Fitz; Winogradsky; Buchner and Meisenheimer. These men of science agreed that the formation of butyric acid by fermentation when using the organisms known to them, was accompanied by secondary reactions, producers of a variety of other substances. For instance, Buchner and Meisenheimer when working with the "Bacillus 
Butyricus" Fitz, found the following products as typical of the fermentation of 100 grams glucose: 0.7 grams butanol; 2.8 grams ethanol; 1.6 grams hydrogen; 3.4 grams formic acid; 10 grams lactic acid; 7.5 grams acetic acid; and 26 grams butyric acid.

Recently, the chemists H. T. Herrick and O. E. May of the Department of Agriculture, Washington, D. C., published a circular on the production of organic acids by fermentation in which they opined that the butyric fermentation had not been applied industrially in commercial magnitude due to the great variety of substances other than butyric acid produced during the fermentation.

The patent literature describes some processes which give the impression that the work has been done in decidedly empirical form. In some cases it is really difficult to understand how a patent could be secured on such vague, indefinite and entirely unscientific data.

\section{Attacking the Problem}

Having acquired from the literature a knowledge of the butyric fermentation whose synopsis is given above, it was resolved to attack the problem of butyric-acid production from waste or final sugar-factory molasses using a native bacillus found by the writer. The work was started during July 1933.

\section{Procedure}

The laboratory work outlined to carry out this investigation consisted in the first place in the preparation of a suitable medium (using blackstrap as raw material) for the propagation and development of the bacteria, and the production of the desired product of fermentation; and in the second place, the determination of the most favorable conditions of carrying this fermentation, leading to maximum yields with minimum expenditures. This meant the preparation of a "Standard Mash" with such physiochemical modifications as would render it the most suitable menstruum for this particular type of bacillus; and the running of fermentation tests to determine :

(1) Ability of the Bacillus to Attack both Sucrose and InvertSugar for Acid production; or its Hydrolytic Power to convert Sucrose into Invert-Sugar, and then these simple Sugars into Acid.

This first step was very important since blackstrap consists essentially of a mixture of sucrose and invert-sugar in the approximate ratio of 2:1 respectively. The result of the experiment would determine the necessity of inverting the sucrose content of the mo- 
lasses, prior to mashing; a process simple enough in the laboratory scale; but that often brings great difficulties of a chemical, economic, and mechanical nature when the same simple reaction is tried in a manufacturing magnitude.

(2) Optimum $p H$ Value.-In industrial fermentation, as well as in all biological processes, the adjustment of the reaction of the nutrient medium is of the utmost importance. A change in the $\mathrm{pH}$ value may vary the end products of microbial metabolism in type and in percentage. Besides, there exists limits in which microbial growth is possible, and each and every group of microorganisms has a definite optimum hydrogen ion concentration for its metabolism.

(3) Optimum Fermentation Temperature.-The external temperature is related to the metabolism of the microbial cell; especially so, due to the poikilothermic nature of bacteria. The external temperature is adjusted in relation to the specific fermentation, keeping in mind that the optimum temperature for growth may not necessarily be the optimum for the production of specific end products. It would be well to mention in this connection that the particular strain of butyric ferment used in this work differed in a marked degree in respect to optimum temperature of fermentation from most others that have been mentioned in the literature; the generally accepted optimum being between 35 and $38 \mathrm{deg}$. C. while in our case we found 30 to $32 \mathrm{deg}$. C. to be the optimum.

(4) Optimum Sugar Concentration.-The importance of this determination is self-evident. The higher the sugar concentration that may be carried during mashing operations compatible with high yields, and ease of fermentation, the better economic results may be obtained when the process is commercially exploited. It means higher unit yields; and economy of equipment, space, power and fuel. In one word: higher net profits.

(5) Use of Activators.-It is well known that there are certain substances that help the fermenting organisms in their work, shortening the duration of fermentation or inereasing the yield; or acting in both of these directions at the same time. Among these, we may mention various forms of carbon such as charcoal, lamp-black, boneblack, activated vegetable chars, as Darco D-4; diatomaceous earth; various inorganic salts as sodium chloride, manganous sulphate, etc., etc.

In his previous investigation for the produetion of butanol and acetone, the writer used some of the above-mentioned substances with great success. As will be shown later on, in the present case 
these activators had no beneficial effect whatsoever when applied to the butyric acid fermentation.

(6) Effect of Substituting Glass Fermenters for Others Made of Different Materials.-This experiment was of great importance from a technical and economic standpoint; since, when transferring the laboratory experimental work to pilot plant operations, glass would hardly be the most adequate material of construction.

(7) Effect of Surface-Volume Ratio.-Another important point of consideration; for sometimes a great variation in yield follows from modifications of this ratio.

(8) Determination of the Advantages of Incorporating Additional Nitrogenous Nutrient to the Mashes Besides Those Found Naturally in the Raw Material.-Blackstrap contains most of the necessary nutrients for microbial growth; its deficiency in this respect being in most cases in nitrogen. The nitrogen content of blackstrap varies considerably with the country where it is produced and appreciably with different localities in the same country. As extremes, may be taken Cuban and Egyptian molasses; the former running on an average of 1.00 to 1.25 percent nitrogen, while the latter runs as low as 0.3 percent and very seldom above 0.5 percent. Puerto Rican molasses runs on the average of 0.65 per cent nitrogen. It was, therefore, found advisable to determine the effect upon fermentation of the addition of a cheap source of inorganic nitrogen, as sulphate of ammonia. As will be seen later on, the results of this experiment were very interesting.

The experimental data in tabular form (with pertinent comments thereon) in connection with the different topies outlined above, will now follow:

(1) Determination of the ability of the bacillus to use both sucrose and invert-sugar for acid production; or its hydrolytic power to convert sucrose into invert-sugar and then these simple sugars into acid.

A set of six mashes was prepared using various mixtures of sucrose and invert-sugar, varying from 100 percent sucrose to 100 percent invert-sugar content. Pure sucrose, laevulose and dextrose were used in the experiment, the mashes being artificially prepared with the addition of blackstrap molasses-ash, and nitrogenous nutrients for the bacteria. The reason to use various mixtures of sucrose and invert-sugar, besides these sugars separately, was due to the belief that while the organism might not be able to attack sucrose in a pure sucrose medium, it might be able to do so when the sucrose was mixed with invert-sugar. The different mashes were autoclaved 
for a half hour at $15 \mathrm{lbs}$. G. P.; cooled down to room-temperature, (about $28^{\circ} \mathrm{C}$.) and inoculated with a pure culture of B. Butyricus.

At definite intervals during the fermentation samples were withdrawn from individual mashes and analyzed for residual sugars.

The results will be found in the table below:

TABLE No. I

\begin{tabular}{|c|c|c|c|c|c|c|c|c|c|}
\hline \multirow{2}{*}{$\begin{array}{l}\text { Mash } \\
\text { No. }\end{array}$} & \multicolumn{2}{|c|}{$\begin{array}{l}\text { Total Sugar } \\
\text { Contert at } \\
\text { Settir g T.me }\end{array}$} & \multicolumn{2}{|c|}{$\begin{array}{c}\text { Total Sugar } \\
\text { Content after } 36 \\
\text { Hours } \\
\text { Fermentation }\end{array}$} & \multicolumn{2}{|c|}{$\begin{array}{c}\text { Total Sugar } \\
\text { Content after } 72 \\
\text { Hours } \\
\text { Fermentation }\end{array}$} & \multicolumn{2}{|c|}{$\begin{array}{l}\text { Total Sugar } \\
\text { Content on } \\
\text { Completion of } \\
\text { Fermentation }\end{array}$} & \multirow{2}{*}{$\begin{array}{l}\text { Comple- } \\
\text { tion of } \\
\text { Fermen- } \\
\text { tion } \\
\text { Hours }\end{array}$} \\
\hline & $\underset{q}{\text { Sucrose }}$ & $\begin{array}{l}\text { Invert } \\
\text { Sugar \% }\end{array}$ & Sucrose & $\begin{array}{l}\text { Invert } \\
\text { Sugar : }\end{array}$ & $\underset{\varnothing}{\text { Sucrose }}$ & $\begin{array}{l}\text { Invert } \\
\text { Sugar } \%\end{array}$ & $\underset{\%}{\text { Sucrose }}$ & $\begin{array}{l}\text { Invert } \\
\text { Sugar } \%\end{array}$ & \\
\hline $\begin{array}{l}1 \ldots \ldots \ldots \\
2 \ldots \ldots \\
3 \ldots \ldots \\
4 \ldots \ldots \\
5 \ldots \ldots \\
6 \ldots \ldots\end{array}$ & $\begin{array}{l}4.50 \\
3.00 \\
2.00 \\
1.00 \\
0.50 \\
0.00\end{array}$ & $\begin{array}{l}0.00 \\
1.50 \\
2.50 \\
3.50 \\
4.00 \\
4.50\end{array}$ & $\begin{array}{l}3.00 \\
1.55 \\
0.85 \\
0.78 \\
0.29 \\
0.00\end{array}$ & $\begin{array}{l}0.50 \\
0.70 \\
1.35 \\
1.40 \\
2.00 \\
2.05\end{array}$ & $\begin{array}{l}1.50 \\
0.70 \\
0.32 \\
0.15 \\
0.00 \\
0.00\end{array}$ & $\begin{array}{l}0.75 \\
0.60 \\
0.64 \\
0.87 \\
1.02 \\
0.98\end{array}$ & $\begin{array}{l}\text { Nil...... } \\
\text { Nil...... } \\
\text { Nil...... } \\
\text { Nil..... } \\
\text { Nil..... } \\
\text { Nil..... }\end{array}$ & $\begin{array}{l}0.45 \\
0.16 \\
0.21 \\
0.23 \\
0.25 \\
0.18\end{array}$ & $\begin{array}{r}120 \\
96 \\
96 \\
92 \\
92 \\
89\end{array}$ \\
\hline
\end{tabular}

The data in Table No. 1 shows in a definite manner that previous inversion of the sucrose content of the molasses became unnecessary, since the B. Butyricus showed in this test its ability to attack both sucrose and invert sugars during fermentation. It shows, moreover, that the bacteria would work at its best in a mixture of these sugars, or in invert-sugars alone, as regards the duration of fermentation. In the case where only sucrose was found in the medium, the bacillus took 24 additional hours to complete the fermentation; leaving besides a higher percentage of residual sugars in the fermented mash. The conclusion was arrived at that blackstrap had very good prospects of being a suitable medium since its approximate sucrose invert-sugar ratio agrees quite closely with conditions represented in mash No. 2. From a technical and economic viewpoint it was very fortunate that no inversion of the sucrose in the molasses became necessary prior to mashing.

(2) Optimum $p H$ Value.--The importance of this determination has been already discussed elsewhere in this paper.

A series of eleven mashes running from $\mathrm{pH} 6.0$ to $\mathrm{pH} 7.0$ were prepared, using blackstrap of initial $\mathrm{pH}$ 5.5. The $\mathrm{pH}$ adjustment at mashing was accomplished $y$ the addition of different amounts of calcium carbonate; and these initial values were maintained in individual mashes during the entire period of fermentation through the use of a 100th normal sodium hydroxide solution. The total sugar concentration of all mashes was 4.5 per cent. This value for total sugar concentration was adopted from the results on Table No. 1, as it was evident that the organism could stand this concentration. 
The most convenient $\mathrm{pH}$ value to use subsequently was to be determined from a consideration of the following items:

a. Starting time of fermentation.

$b$. General apparent activity during fermentation.

c. Finishing time of fermentation.

d. Residual sugar content of mashes.

$e$. Yield of Total Acidity.

TABLE No. 2

\begin{tabular}{|c|c|c|c|c|c|c|c|}
\hline \multirow[b]{2}{*}{$\begin{array}{l}\text { Mash } \\
\text { No. }\end{array}$} & \multirow[b]{2}{*}{$\underset{\text { value }}{\mathrm{pH}}$} & \multicolumn{3}{|c|}{ Fermentation } & \multirow[b]{2}{*}{$\begin{array}{l}\text { Residual } \\
\text { Sugars }\end{array}$} & \multirow{2}{*}{$\begin{array}{c}\text { Total } \\
\text { Acidity } \\
\text { Grams }\end{array}$} & \multirow{2}{*}{$\begin{array}{c}\text { Total Acid } \\
\text { Yield } \& \\
\text { Total } \\
\text { Sugars }\end{array}$} \\
\hline & & $\begin{array}{l}\text { Time } \\
\text { taken to } \\
\text { start }\end{array}$ & $\begin{array}{l}\text { Time } \\
\text { taken to } \\
\text { flnish }\end{array}$ & $\begin{array}{l}\text { General } \\
\text { activity }\end{array}$ & & & \\
\hline & 6.0 & 18 hrs... & $101 \mathrm{hrs} . . .$. & Fair.. & 0.51 & 1.41 & 31.4 \\
\hline & 6.1 & $18 \mathrm{hrs} . . . .$. & $101 \mathrm{hrs} . . .$. & Frir... & 0.49 & 1.43 & 31.8 \\
\hline $3 \ldots$ & 6.2 & $18 \mathrm{hrs} . . .$. & 100 hrs.... & Fair... & 0.43 & 1.47 & 32.7 \\
\hline $4 \ldots \ldots$ & 6.3 & 18 hrs..... & 98 hrs.... & Fair... & 0.38 & 1.46 & 32.5 \\
\hline $5 \ldots \ldots$ & 6.4 & 16 hrs.... & 98 hrs.... & Fair.. & 0.30 & 1.48 & 32.9 \\
\hline $6 \ldots \ldots$ & 65 & $16 \mathrm{hrs} . . .$. & 96 hrs.... & Good.. & 0.26 & 1.55 & 34.6 \\
\hline & 6.6 & 14 hrs..... & 96 hrs.... & Good... & 0.22 & 1.56 & 34.7 \\
\hline $8 \ldots \ldots$ & 6.7 & 14 hrs..... & 96 hrs.... & Good....... & 0.20 & 1.57 & 34.8 \\
\hline & 6.8 & $12 \mathrm{hrs} . . .$. & 90 hrs.... & Very Good.. & 0.18 & 1.61 & 35.9 \\
\hline $10 .$. & 6.9 & $10 \mathrm{hrs.....}$ & $88 \mathrm{hrs} . .$. & Very Good.. & 0.16 & 1.61 & 35.9 \\
\hline & 7.0 & $10 \mathrm{hrs.....}$ & 88 hrs.... & Very Good.. & 0.16 & 1.63 & 36.2 \\
\hline
\end{tabular}

From a consideration of the data on Table 2, it appears that the optimum $\mathrm{pH}$ value was from $\mathrm{pH} 6.8$ to $\mathrm{pH}$ 7.0. Later developments proved that the best practice was to add at once all of the calcium carbonate necessary to neutralize the acid produced during the fermentation. The actual $\mathrm{pH}$ values on mashes thus prepared generally ran between $\mathrm{pH} 7.0$ to $\mathrm{pH} 7.2$ as the initial value; these values changing to a range between $\mathrm{pH} 6.6$ and $\mathrm{pH} 6.9$ on completion of the fermentation.

(3) Determination of Optimum Temperature of Fermentation.Although the literature on this subject stated that most butyric acid organisms worked better at from $35^{\circ}$ to $38^{\circ} \mathrm{C}$., we had carried our two previous fermentation tests at room temperature (about $28^{\circ} \mathrm{C}$.) with apparent satisfactory results. This decided us to try a range of from $28^{\circ}$ to $40^{\circ} \mathrm{C}$. for determining the optimum for this particular strain.

Thirteen sets of six mashes each were prepared, and each set fermented at a different temperature from $28^{\circ}$ to $40^{\circ} \mathrm{C}$. As it would have taken too much space to report the results of the different individuals in each set, the following table has been prepared giving the average results obtained in each. All conditions of fermentation excepting the temperature factor were maintained constant for all sets. 
TABLE No. 3

\begin{tabular}{|c|c|c|c|c|c|c|c|c|}
\hline $\begin{array}{c}\text { Mash } \\
\text { Set } \\
\text { No. }\end{array}$ & $\begin{array}{l}\text { Ferm. } \\
\text { Temp. } \\
{ }^{\circ} \mathrm{C} \text {. }\end{array}$ & $\begin{array}{c}\text { Duration } \\
\text { of Ferm. } \\
\text { Hrs. }\end{array}$ & $\begin{array}{l}\text { \% Total } \\
\text { Sugare in } \\
\text { Mash }\end{array}$ & $\begin{array}{l}\$ \text { Residual } \\
\text { Sugars } \\
\text { after } \\
\text { Fermen- } \\
\text { tation }\end{array}$ & $\begin{array}{c}\text { Sugars } \\
\text { Fermented } \\
\text { \% Total } \\
\text { Sugars }\end{array}$ & $\begin{array}{l}\text { Yield T. } \\
\text { Acidity \% } \\
\text { on Mash }\end{array}$ & $\begin{array}{l}\text { Yield T. } \\
\text { Acidity \% } \\
\text { on T. } \\
\text { Sugars }\end{array}$ & $\begin{array}{l}\text { Yield T. } \\
\text { Acidity } \% \\
\text { on Sugars } \\
\text { Fermented }\end{array}$ \\
\hline $\begin{array}{r}1 \ldots \ldots \\
2 \ldots \ldots \\
3 \ldots \ldots \\
4 \ldots \ldots \\
5 \ldots \ldots \\
6 \ldots \ldots \\
7 \ldots \ldots \\
8 \ldots \ldots \\
9 \ldots \ldots \\
10 \ldots \ldots \\
11 \ldots \ldots \\
12 \ldots \ldots \\
13 \ldots \ldots\end{array}$ & $\begin{array}{l}28 \\
29 \\
30 \\
31 \\
32 \\
33 \\
34 \\
35 \\
36 \\
37 \\
38 \\
39 \\
40\end{array}$ & $\begin{array}{r}108 \\
100 \\
96 \\
96 \\
96 \\
96 \\
96 \\
92 \\
92 \\
92 \\
90 \\
90 \\
88\end{array}$ & $\begin{array}{l}4.50 \\
4.50 \\
4.50 \\
4.50 \\
4.50 \\
4.50 \\
4.50 \\
4.50 \\
4.50 \\
4.50 \\
4.50 \\
4.50 \\
4.50\end{array}$ & $\begin{array}{l}0.16 \\
0.19 \\
0.15 \\
0.16 \\
0.16 \\
0.19 \\
0.21 \\
0.25 \\
0.40 \\
0.49 \\
0.53 \\
0.65 \\
0.81\end{array}$ & $\begin{array}{l}96.44 \\
95.77 \\
96.66 \\
96.44 \\
96.44 \\
95.77 \\
95.33 \\
94.44 \\
91.11 \\
89.11 \\
88.22 \\
85.55 \\
82.00\end{array}$ & $\begin{array}{l}1.69 \\
1.66 \\
1.69 \\
1.70 \\
1.71 \\
1.65 \\
1.63 \\
1.61 \\
1.52 \\
1.47 \\
1.45 \\
1.38 \\
1.29\end{array}$ & $\begin{array}{l}37.55 \\
36.88 \\
37.55 \\
37.77 \\
38.00 \\
36.66 \\
36.22 \\
35.77 \\
33.77 \\
32.66 \\
32.22 \\
30.66 \\
28.66\end{array}$ & $\begin{array}{l}39.05 \\
38.45 \\
38.90 \\
39.15 \\
39.42 \\
38.21 \\
38.00 \\
37.84 \\
37.16 \\
36.70 \\
36.55 \\
35.92 \\
34.89\end{array}$ \\
\hline
\end{tabular}

From a perusal of Table No. 3 it will be apparent that optimum fermentation temperature lies in the range $30^{\circ}-32^{\circ} \mathrm{C}$. This places our strain fully in the mesophilic range.

It is true that at $28^{\circ} \mathrm{C}$. the bacillus seems to work almost as well in so far as yield is concerned, but it will be noticed that twelve additional hours are required in this case to carry fermentation to completion, and this is a fact that must be reckoned with when working in commercial scale. A few hours are gained in finishing the fermentation when working at higher temperatures, say, from 38 to $40^{\circ}$ C.; but the comparatively low yields of total acidity more than offset this advantage. The great difference in yields is specially apparent in the column of the table under the heading "Total Acidity Yield Percent on Total Sugars"; when a difference of over 9.0 percent is found between results of Mash Set No. 5 and 13 .

This ability to work at its best at rather low temperatures is characteristic of this particular strain of B. Butyricus as already pointed out, differentiating it from most other known bacteria of this genus.

(4) Determination of Optimum Sugar Concentration.-To find out this very important point, the following experiment was carried out:

A set of seven mashes was prepared using ascending values of sugar concentration from 4.59 to 8.52 percent. Optimum conditions previously determined were used in this test, and all factors except that of percentage sugar concentration were kept constant.

The results will be found on Table No. 4. 
TABLE No. 4

\begin{tabular}{|c|c|c|c|c|c|c|c|}
\hline $\begin{array}{l}\text { Mash } \\
\text { No. }\end{array}$ & $\begin{array}{l}\text { T. Sugars } \\
\text { Content } \\
\text { Grams }\end{array}$ & T. Sugars & T. Solids & $\begin{array}{c}\text { Ferment. } \\
\text { Time } \\
\text { Hrs. }\end{array}$ & $\underset{\substack{\text { Residual } \\
\text { Sugars }}}{\text {. }}$ & $\begin{array}{l}\text { T. Acidity } \\
\text { Yield } \\
\text { Grams }\end{array}$ & $\begin{array}{l}\text { T Acidity } \\
\text { Yield } \% \\
\text { T Sugars }\end{array}$ \\
\hline 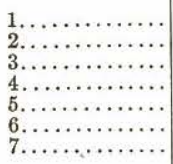 & $\begin{array}{l}18.37 \\
21.00 \\
23.60 \\
26.30 \\
28.90 \\
31.50 \\
34.10\end{array}$ & $\begin{array}{l}4.59 \\
5.25 \\
5.90 \\
6.58 \\
7.22 \\
7.88 \\
8.52\end{array}$ & $\begin{array}{r}7.40 \\
8.50 \\
9.60 \\
10.60 \\
11.70 \\
12.80 \\
13.80\end{array}$ & $\begin{array}{r}95 \\
95 \\
96 \\
96 \\
98 \\
102 \\
108\end{array}$ & $\begin{array}{l}0.15 \\
0.18 \\
0.16 \\
0.15 \\
0.25 \\
0.55 \\
0.75\end{array}$ & $\begin{array}{r}8.43 \\
9.69 \\
10.83 \\
12.22 \\
12.78 \\
12.29 \\
13.00\end{array}$ & $\begin{array}{l}45.90 \\
46.15 \\
45.91 \\
46.50 \\
44.22 \\
39.01 \\
38.12\end{array}$ \\
\hline
\end{tabular}

The above figures show that optimum sugar concentration lies at 6.58 percent. At this concentration the total acidity yield percent on total sugar content of mash is the highest, while the duration of fermentation is fairly good. At sugar concentrations below this, down to 4.59 percent good results are also obtainable as regards percentage yield on sugars; but it will be noticed that the absolute unit yield, i. e. grams acidity per mash distilled, is of course much higher at the optimum of 6.58 percent sugars. On the other hand, when we try to increase the sugar concentration above 6.58 percent, descending yield values are obtained, which are quite noticeable specially when using concentrations of 7.88 percent and 8.52 percent respectively. In these cases, besides, we have an increasing value in residual sugars, and in duration of fermentation. Moreover, the absolute yields are in one case lower than at optimum concentration, and in the other case the slight increase is more than offset by the much higher percentage of sugars used in the preparation of the mash, and the much higher loss in residual sugars. From the above considerations we decided to adopt 6.58 percent as the optimum value for sugar concentration.

(5) Effect of Activators.-The beneficial effects to be usually expected from the use of activating agents in industrial fermentation work affect either the yield or the duration of fermentation, or both of these factors. We decided to try only cheap materials, some of which we had successfully used in our previous researches on the aceto-butylic fermentation work. Those selected were: Lamp Black; Bone Black; Wood Charcoal; Dareo D-4; and Infusorial Earth.

For this determination six sets of mashes were prepared, using a different activating agent in each of the first five, and the remaining one was used as a check, no activator being added. The activating substances were used in different quantities in individual members of each set, and all optimum conditions previously determined were maintained during these tests. 
To avoid using too much space only the average results obtained from each experimental set are recorded in Table No. 5 below:

TABLE NO. 5

\begin{tabular}{|c|c|c|c|c|c|}
\hline $\begin{array}{c}\text { Mash } \\
\text { Set No. }\end{array}$ & Activator Used & $\begin{array}{c}\text { Ferment } \\
\text { Time } \\
\text { Hours }\end{array}$ & $\underset{\substack{\text { Residual } \\
\text { Sugars }}}{ }$ & $\begin{array}{l}\text { Total } \\
\text { Yield } \\
\text { Grams }\end{array}$ & $\begin{array}{l}\text { Total } \\
\text { Acidity } \\
\text { Yield \% } \\
\text { Total } \\
\text { Sugars }\end{array}$ \\
\hline 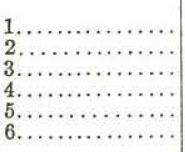 & 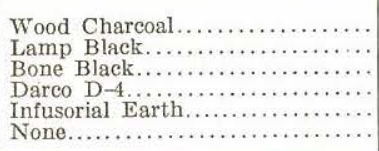 & $\begin{array}{r}102 \\
98 \\
100 \\
96 \\
102 \\
96\end{array}$ & $\begin{array}{l}0.27 \\
0.21 \\
0.19 \\
0.18 \\
0.23 \\
0.18\end{array}$ & $\begin{array}{l}11.78 \\
11.97 \\
12.00 \\
12.15 \\
11.87 \\
12.40\end{array}$ & $\begin{array}{l}44.79 \\
45.7 .1 \\
45.62 \\
46.19 \\
45.13 \\
47.14\end{array}$ \\
\hline
\end{tabular}

The results of Table No. 5 hardly need discussion. From a consideration of the figures under the columns headed "Fermentation Time" and "Total Acidity Yield Percent on Total Sugars" it is obvious that neither the duration of fermentation nor the percentage yield were increased by the use of activators. As a matter of fact, the best results were obtained when no activating substances were used.

(6) Effect of Substituting Glass Fermenters for Others Made of Different Materials.-For this test, fermenters made out of (1) Sheet Iron; (2) Copper; (3) Enamelled Iron; and (4) Wood, were substituted for the glass fermenters used in all the previous tests.

A set of 6 mashes was made for each kind of fermenter used; all other conditions except the material of construction of the fermenters in the different sets, being kept the same.

On table No. 6 below, will be found the average results obtained in each case.

TABLE No. 6

\begin{tabular}{|c|c|c|c|c|c|c|c|c|}
\hline $\begin{array}{l}\text { Mash } \\
\text { Set } \\
\text { No. }\end{array}$ & $\begin{array}{l}\text { Kind of } \\
\text { Fermenters Used }\end{array}$ & $\begin{array}{l}\text { Total } \\
\text { Sugars } \\
\text { Grams }\end{array}$ & $\begin{array}{c}\text { Ferment. } \\
\text { Time } \\
\text { Hrs. }\end{array}$ & $\begin{array}{c}\text { Residual } \\
\text { Sugars } \\
\text { Grams }\end{array}$ & $\begin{array}{l}\text { Sug. } \\
\text { Ferm } \% \\
\text { T. Sugars }\end{array}$ & $\begin{array}{l}\text { Acid } \\
\text { Prod. } \\
\text { Grams }\end{array}$ & $\begin{array}{l}\text { Acid } \\
\text { Prod. } \% \\
\text { T. Sug. }\end{array}$ & $\begin{array}{l}\text { Acid } \\
\text { Prod. } \% \\
\text { Sug. } \\
\text { Form. }\end{array}$ \\
\hline $\begin{array}{l}1 \ldots \ldots \\
2 \ldots \ldots \ldots \\
3 \ldots \ldots \\
4 \ldots \ldots\end{array}$ & $\begin{array}{l}\text { Iron................ } \\
\text { Copper.... } \\
\text { Enamelled Iron... } \\
\text { Wood............. }\end{array}$ & $\begin{array}{l}26.30 \\
26.30 \\
26.30 \\
26.30\end{array}$ & $\begin{array}{l}60.00 \\
* 0.00 \\
96.00 \\
92.00\end{array}$ & $\begin{array}{r}1760 \\
26.30 \\
0.58 \\
0.42\end{array}$ & $\begin{array}{r}33.46 \\
0.00 \\
97.79 \\
98.40\end{array}$ & $\begin{array}{r}1.93 \\
0.00 \\
12.07 \\
12.15\end{array}$ & $\begin{array}{r}7.33 \\
0.00 \\
45.90 \\
46.18\end{array}$ & $\begin{array}{r}22.15 \\
0.00 \\
46.92 \\
46.94\end{array}$ \\
\hline
\end{tabular}

*In the case of the copper fermenters, fermentation never started.

The above results show in a definite manner that metallic fermenters are inhibitive to the bacterial action, copper especially so. In the case of enamelled iron and wood the results are in all respects comparable with those obtained when using glass fermenters. 
(7) Effect of Surface-Volume Ratio.-This test was of particular importance in a study of this nature, where the ultimate objective of the work is the establishment of this process in commercial magnitude should the final result warrant such action.

Six sets of mashes were prepared as usual; the only variable this time being the amount of individual mash used in each set. The sizes of mash for the different sets were selected as follows : $100 \mathrm{ml}$; $250 \mathrm{ml}$; $250 \mathrm{ml}$; $500 \mathrm{ml}$; $1000 \mathrm{ml}$; $2000 \mathrm{ml}$; and $4000 \mathrm{ml}$. Care was taken to add the same percentage of inoculant based on total mash volume in all cases; the percentage used being 5 .

Average results obtained in each set are recorded in Table No. 7.

\begin{tabular}{|c|c|c|c|c|c|}
\hline $\begin{array}{c}\text { Mash Set } \\
\text { No. }\end{array}$ & $\begin{array}{l}\text { Size of Mash } \\
\text { Ml. }\end{array}$ & $\begin{array}{l}\text { Fermentation } \\
\text { Time Hours }\end{array}$ & $\begin{array}{l}\text { Residual } \\
\text { Sugars } \%\end{array}$ & $\begin{array}{l}\text { Total Acidity } \\
\text { Yield \% } \\
\text { Total Sugars }\end{array}$ & $\begin{array}{c}\text { Fermentation } \\
\text { Efficiency } \% \\
\text { Theoretical } \\
\text { Yield }\end{array}$ \\
\hline 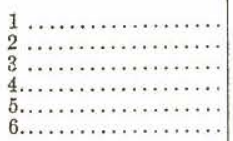 & $\begin{array}{r}100 \\
250 \\
500 \\
1000 \\
2000 \\
4000\end{array}$ & $\begin{array}{r}120 \\
105 \\
96 \\
96 \\
88 \\
86\end{array}$ & $\begin{array}{l}0.26 \\
0.22 \\
0.19 \\
0.18 \\
0.20 \\
0.18\end{array}$ & $\begin{array}{l}45.15 \\
45.90 \\
46.40 \\
46.90 \\
47.10 \\
47.50\end{array}$ & $\begin{array}{l}92.33 \\
93.86 \\
94.88 \\
95.91 \\
96.31 \\
97.13\end{array}$ \\
\hline
\end{tabular}

The results shown on table No. 7 are quite satisfactory as regards the surface volume ratio effect. As the ratio decreases, i. e. as the volume of mash is increased, it may be noticed that not only the yields of total acidity based on Total Sugars, and the Fermentation Efficiencies increase; but that also the duration of the fermentation is shortened at the same time. The results give us reasonable assurance that in plant operation no fears need be felt as to the possible effect of working in large-capacity fermenters.

(8) Influence of Incorporating Additional Nitrogenous Nutrient to the Mashes, besides the Natural Nutrients of the Molasses itself.In our previous investigation on butanol and acetone production by fermentation, we had noticed a marked rise in yield of solvents from the use of sulphate of ammonia during mashing to the extent of 1 percent on weight of molasses used. Moreover, we also noticed a shortening in the duration of fermentation when this nutrient was added. These facts decided us to try the experiment in the present case, although our present yields were so high that they could hardly stand much improvement without reaching the theoretical limit.

For the experiment, seven sets of mashes were prepared. In six of these sets, ammonium sulphate was added in increasing quantities 
from $0.5 \mathrm{gr}$. to $1.0 \mathrm{gr}$.; while set No. 7 was run as a check with no addition of this salt.

During the fermentation of the sets containing added sulphate of ammonia, the characteristic odor of hydrogen sulphide could be noticed in the incubator. This was not the case when the check set was fermenting nor had we noticed this phenomenon in our previous work. We concluded that the gas originated from the reducing action of the organism upon the sulphate of ammonia.

The generation of this obnoxious gas during fermentation would have been objectionable enough; but the fact that no beneficial effect could be observed from the use of the sulphate of ammonia, decided us against its further use.

Table No. 8 below presents the data obtained during the above experiment.

TABLE No. 8

\begin{tabular}{|c|c|c|c|c|c|}
\hline $\begin{array}{l}\text { Mash Set } \\
\text { No. }\end{array}$ & $\begin{array}{c}\text { Ammonia } \\
\text { Sulphate } \\
\text { Added, Grams }\end{array}$ & $\begin{array}{l}\text { Fermentation } \\
\text { Time Hours }\end{array}$ & $\begin{array}{l}\text { Residual } \\
\text { Sugars \% }\end{array}$ & $\begin{array}{l}\text { Total Acidity } \\
\text { Yield } \% \\
\text { Total Sugars }\end{array}$ & $\begin{array}{c}\text { Generation } \\
\text { of Hydrcgen } \\
\text { Sulphide }\end{array}$ \\
\hline 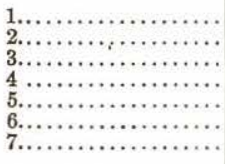 & $\begin{array}{r}0.5 \\
0.6 \\
0.7 \\
0.8 \\
0.9 \\
1.0 \\
\text { None........... }\end{array}$ & $\begin{array}{r}100 \\
102 \\
104 \\
106 \\
106 \\
110 \\
95\end{array}$ & $\begin{array}{l}0.28 \\
0.29 \\
0.29 \\
0.35 \\
0.44 \\
0.21 \\
0.16\end{array}$ & $\begin{array}{l}46.50 \\
46.50 \\
46.27 \\
45.91 \\
45.62 \\
45.24 \\
47.01\end{array}$ & $\begin{array}{l}\text { Yes } \\
\text { Yes } \\
\text { Yes } \\
\text { Yes } \\
\text { Yes } \\
\text { Yes } \\
\text { None }\end{array}$ \\
\hline
\end{tabular}

\section{The Standard Mash}

The knowledge and experience gained through the work effected above, led us to the formulation of the "Standard Mash" for the production of Normal Butyric Acid from blackstrap. We had found that such a mash should possess the following characteristics:

a. A $\mathrm{pH}$ value of 6.8 to 7.0

b. Density of 10.6 deg. Brix

c. Total Sugar Concentration of 6.58 percent

and that its fermentation was to be carried at temperatures of from $30-32^{\circ} \mathrm{C}$., without the necessity of inverting the sucrose or of incorporating any extraneous bacterial nutrient in addition to that already present in the blackstrap.

After some experiments, it was decided to make the Standard. Mash as follows:

To one part molasses by weight, 7 parts water are added. Then to this diluted molasses, 0.135 part calcium carbonate is added. This mixture is autoclaved at $10 \mathrm{lbs}$. G. P. for 30 minutes, and after cool- 
ing to the desired temperature, the mash is ready for inoculation. Determinations of $\mathrm{pH}$ in mashes thus prepared, gave values between 6.8 and 7.2 ; densities between 10.5 and $10.8^{\circ}$ Brix and total sugar concentrations between 6.4 and 6.8 percent using average P. R. molasses.

To illustrate, suppose we wish to mash up 100 grams molasses: Add 700 grams water and 13.5 grams calcium carbonate; then sterilize and cool. Simpler mashing operations are not found anywhere in industrial fermentation work.

On Table No. 9 will be found the results of an "Over-All Efficiency Test" run with a series of ten mashes prepared according to directions given above for the "Standard Mash".

The analysis of the blackstrap was:

Degree Brix 85. 60

Total Sugars (as Invert) 52.50

Nitrogen percent

$\mathrm{pH}$ value

5.5

The analysis of the resulting mash was:

Degree Brix 10. 80

Total Sugars (as Invert)-_-_-_-_-_-

Nitrogen percent

6. 50

$\mathrm{pH}$ value 


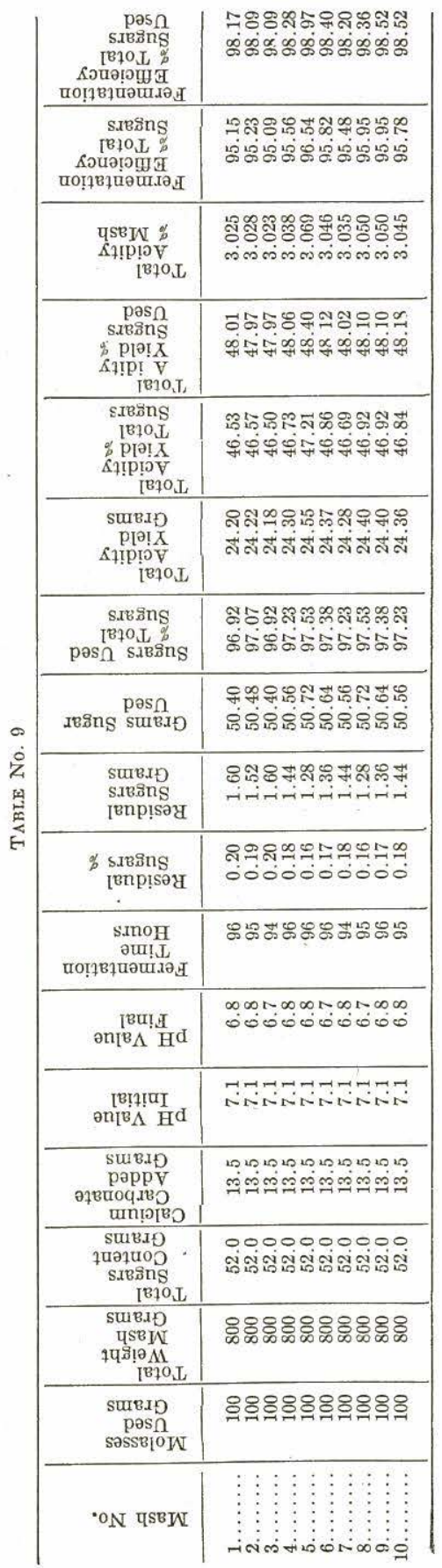


According to the data on Table No. 9, the bacillus butyricus used in this research, when working on "Standard Mash" under optimum conditions of fermentation, possesses the power to:

a. Finish the fermentation in from 94 to 96 hours.

b. Use from 96 to 97.5 percent of the sugar content of the mash in this time.

c. Give a yield equivalent to :

(1) 46 to 47 percent on T. Sugars.

(2) 47 to 48.5 percent on Sugars Used.

(3) 3.00 percent on Mash Weight.

d. Show a fermentation efficiency (based on theoretically possible yield) of 95 to 96.5 percent on total sugars, and 98 to 98.5 percent on sugars used.

\section{Acid Extraction From the Fermented Mash}

The method of separating the acid from the fermented mash was as follows:

The first step was to try the reaction of the fermented mash towards litmus paper. If the reaction was acid, then the mash was brought to neutralization by the addition of ealcium hydroxide or carbonate.

The neutral, or slightly alkaline mash, was then evaporated down to one-fourth its original volume, preferably under vacuum. At this point the thickened mash was treated with enough sulphuric acid to liberate the fatty acid from its calcium salt, and the mixture was steam-distilled until all of the volatile fatty acid had passed over. In this way a dilute aquous solution of the acid originally present in the mash was obtained. Usually, the acid was recovered from the water solution in the form of its barium salt.

\section{Products of Fermentation}

The fermentation produced by the butyric acid bacillus strain discovered and isolated by the writer when operating in blackstrap molasses results in the production of:

1. N. Butyric Acid

2. Hydrogen gas

3. Carbon dioxide gas

the reaction taking place being as follows:

$$
\mathrm{C}_{6} \mathrm{H}_{12} \mathrm{O}_{6}+\text { Ferment }=\mathrm{CH}_{3} \cdot \mathrm{CH}_{2} \cdot \mathrm{CH}_{2} \cdot \mathrm{COOH}+{ }_{2} \mathrm{H}_{2}+{ }_{2} \mathrm{CO}_{2}
$$

Of these three products the normal butyric acid is, of course, the most valuable; but mention must be made here that the other two 
gaseous products may be made to combine through the agency of high temperature and pressure and of some suitable catalyst to produce the purest form of methanol known to industry.

The normal butyric acid is produced in almost theoretical yield, and of a splendid degree of purity - 99 percent or better, pure butyric acid. And this fact constitutes the outstanding merit of this process. It is only on very rare occasions that a fermentation product is obtained in such an extraordinary degree of purity.

The writer, after becoming awared of this most extraordinary fact, wished to have his work checked by two independent laboratories. The laboratory of the Bureau of Chemistry at Washington, D. C., and the private laboratory of Dr. Donald F. Othmer, professor of industrial chemistry at the Brooklyn Polytechnic, were selected. Samples of about 200 grams each of the barium salt of the acid were sent to these laboratories. The two reports received were identical, both laboratories reporting the material as practically pure butyrate of barium. Dr. Othner's report further specified that the acid extracted from the barium salt proved to be 99 percent or over, pure butyric acid. That the impurities (if present) could not be determined due to their being present in traces, and the sample of material being so small.

The splendid purity of the acid obtained by this fermentation is of paramount importance should the attempt be made to develop the process in commercial scale. One of the most expensive stages of the plant work, that of purification, would be eliminated from the start. The highest grade of butyric acid now in the market only guarantees from 98 to 99 percent purity; and this is only obtainable in their case, after much and laborious refractionation and purification; while here we have a natural product of practically C.P. quality.

\section{Other Fermentation Tests}

The work so far described above, strengthened the belief in the writer's mind that his discovery and process could possibly be applied in commercial magnitude. With this idea in mind, new tests were planned and executed that would result in increasing its range of usefulness, or lowering the cost of producing the acid.

Due to lack of space, the new experiments performed will not be given in detail; but the results obtained will be briefly commented.

To test the ability of the organism to work without absolute sterilization of the medium, a series of experiments were performed in which pressure cooking of the mashes was eliminated. Instead, the 
mashes were prepared by heating to $100^{\circ} \mathrm{C}$. at atmospheric pressure during five minutes. The results obtained were in all respects comparable to those produced when working with absolute sterilization under pressure. This encouraged us to go a step further in the same direction, using no heating at all of the mashes before inoculating with the bacillus. Results were again entirely satisfactory comparing favorably with those obtained previously with total and partial sterilization of the medium.

The economic importance of these later tests is self-evident; for, should it be possible to duplicate the experimental results in large scale, normal butyric acid of the highest purity could be produced at extremely low price, not more than a few cents per pound.

Through the courtesy of Mr. Herman Schreibler, consulting chemist of Lansing, Michigan, a sample of final beet molasses was made available to the writer for experimental purposes. The work performed on sugar cane final molasses was duplicated using this beet molasses as raw material; the same satisfactory results being obtained as to ease of fermentation, high yield and purity, of the finished product.

Also, and more recently; through the courtesy of the "Sucesion Serrallés" of Ponce, P. R., the bacillus was put to work on samples of Distillery Slops, for the conversion of the residual sugars contained in this waste material into butyric acid. It is highly significant, both from a purely scientific and industrial viewpoints, that although the Distillery Slops furnished by the "Sucesión Serrallés" contained, on the average, only about one percent of residual sugars; the organism succeeded in transforming them into the acid, almost quantitatively.

\section{Uses of Butyric ACID}

\section{(Present and Future)}

Due to its present high price (varying between 35 and 80 eents a pound, according to purity of material and quantities bought) Normal Butyric Acid finds most of its use in the Ester Industry. In this field, its application is divided mainly between the Flavor Industry and that of Perfumery and Cosmetics.

In these above mentioned industries we find butyric acid derivatives as Rhodinol; Propyl; Pheny-Ethyl; Octyl; Linalyl; Iso-butyl; Geranyl; Citronellyl; Cinnamyll; Butyl and Benzyl Butyrates. Also Capryl-Butyric Acid and Butyric Ketone (Butyrone). The prices of these derivatives very between $\$ 1.35$ and $\$ 32$ per pound.

Butyric acid derivatives in an impure form are beginning to ap- 
pear in the Solvents Industry. "Amyl Ketol" is one of these products, consisting mainly of Butyrone. It is used as a solvent for both cellulose acetate and for nitrate of high nitrogen content; it also dissolves caoutchouc, ester gum, cumarone, linseed and castor oils, glyceryl phthalate and other resins. It is miscible with hydrocarbons. It possesses a rather sweet odor resembling pineapples, and is non-toxic at normal working concentrations.

The future uses of butyric acid in industry, will depend, in a great measure upon the price at which the commodity may be made available. As possible fields of application we may mention the (1) Leather Industry where it would serve as a softener, deliming agent; (2) Lacquer Industry, in the manufacture of plasticisers; (3) Varnish Industry, in the manufacture of Dryers; (4) Cellulose Esters; and (5) Pharmaceutical and Drugs.

The writer has also, of late, been using butyric acid in the preparation of a high grade alpha-cellulose pulp from cane bagasse and foliage. Results to date are entirely satisfactory.

\section{ACKNOWLEDGMENTS}

The writer gratefully acknowledges his indebtedness to Dr. D. F. Othmer, professor of chemical engineering at Brooklyn Polytechnic Institute for his painstaking work in checking up the purity of the acid produced, and for the general interest he has taken throughout all the time that this investigation was taking place; to Dr. W. L. Owen, consulting bacteriologist of Baton Rouge, La., for his kind advice and early appreciation of the industrial possibilities of this discovery; to the Bureau of Chemistry of Washington, D. C., for the corroborative analysis on the barium salt of the acid produced; and finally to $\mathrm{Mr}$. Herman Schreibler, consulting chemist of Lansing, Michigan; through whose kindness and interest the work on final beet molasses was made possible.

\section{SUMmary}

1. The ultimate aim of this research was to find an inexpensive biochemical method for the production of Normal Butyric Acid from Blackstrap.

2. A native organism was found and isolated in pure culture which proved admirably adapted to this purpose.

3. Difficulties experienced by previous investigators were obviated in the course of the above described work.

4. The process is simple, inexpensive, and merits further efforts towards its industrial application and commercial exploitation. 
5. The main end product of fermentation (Normal Butyric Acid) is obtained in nearly theoretical yield, and of a splendid degree of purity: 99 percent or better.

6. It is the writer's intention to apply for patent rights protection for his discovery and process.

\section{REFERENCES}

1. Effront, J. Process of Fermenting Organic Nitrogenous Substances. U. S. Patent 953025. 1910.

2. Le Franc, L. Manufacture of Acids of the Fatty Series and of Butyric Acid in Particular by Fermentation. British Patent 17776. 1914.

3. Dupont, I. Process for the Utilization of Marine Algae for the Manufacture of Acetic and Butyric Acids.

4. Mc-Dermott, F. A. and Glascow, R. Manufacture of Butyric Acid. U. S. Patent 1405,055. 1922.

5. Sinclair, W. W. Process of Manufacture of Aldehydes, Oils, and Organic Acids from Cacti.

6. Le Frank, I. Manufacture of Butyric Acids and other Aliphatic Acids. U. S. Patent 1,625,732. 1927.

7. Le Ketol. Butyric Acid. French Patent 662,321. 1928.

8. Botkin, S. Ueber einen Bacillus Butyricus. Ztschr. f. Hyg. U. Infk. 11: 421-434.

9. Duclaux, E. Sur la Nutrition Intra-Cellulaire. Ann. d. 1. I. Past. 9: 811-839. 1895.

10. Fernbach, A., and Strange, E. H. Production of Amyl, Butyl, and Ethyl Alcohol, and Butyric, Proprionic or Acetic Acid, etc. British Patent, 15203. 1911.

11. Krumnwiede, C., Jr. and Pratt, J. Fusiform Bacilli-Isolation and Cultivation. Jour. Inf. Dis., 12: 199-201. 1913.

12. Dyer, D. C. A. A New Method for Steam Distillation for the Determination of Volatile Fatty Acids, etc. Jour. Biol. Chem. 28: 445-473. 1917.

13. Fitz, A. Ein Neues Butter-säureferment.

14. Desporment, E. Procédé De Production de l'Acide Butyrique et des Acides de la Série Grasse par Fermentation directe des Farines, Amidons, et des Produits Amylacés sans Saccharification Préalable. Fr. Pt. 662, 321, March 18, 1929.

15. Société D'Etude de Carbure. Procédé de Fabrication Industrielle Des Acides de la Série Grasse, et en Particulier d l'Acide Butyrique. F. Pt. 469552. Mag. 23. 1914.

16. Arroyo, R. The Utilization of Waste Molasses in the Production of (I-) Butanol and Acetone. (II-) Normal Butyric Acid. The Journal of Agriculture of the University of P. R. Vol. 18 (4). Oct. 1934. 